\title{
Effects of land use and irrigation intensity on the transport of iodide in structured clay loam soil
}

\author{
${ }^{1}$ Á. Horel, ${ }^{2}$ L. Lichner, ${ }^{3}$ R. Kodesova, \\ and ${ }^{2}$ V. STEKAUEROVA ${ }^{\dagger}$
}

\begin{abstract}
${ }^{1}$ Institute for Soil Science and Agricultural Chemistry of the Centre for Agricultural Research, Hungarian Academy of Sciences, Budapest; ${ }^{2}$ Institute of Hydrology, Slovak Academy of Sciences, Bratislava and ${ }^{3}$ Dept. of Soil Science and Soil Protection, Faculty of Agrobiology Food and Natural Resources, Czech University of Life Sciences Prague, Prague, ${ }^{\dagger}$ Deceased
\end{abstract}

\section{Introduction}

In agriculturally cultivated areas, water and nutrient movement through the soil matrices has a crucial role for achieving good crop growth and yield. Soil structure can be very vulnerable in terms of climatic conditions. As most climate change scenarios predict an increase in the frequency of intensive rainfall events, cultivated land may be extremely susceptible for soil erosion or flooding (ZIADAT \& TAIMEH 2013). Many agriculturally cultivated areas might experience changes in the frequency and intensity of rains, which might be followed by extensive dry periods (FARKAS et al., 2014; FAŠKO et al., 2008; HARDY, 2003).

Rain events that have different time scales also have different effects on the soil crust and can influence the rate of local erosion or flooding (HAERTER et al., 2010); consequently the increased intensity and duration of local rain events may promote soil degradation and solute leaching to below the root zone. Irrigation intensities can influence overall soil health by changing the rate of oxygen flux, which is very important for crop growth in the root zone. For example, high irrigation intensity, such as $18 \mathrm{~mm} \cdot \mathrm{h}^{-1}$ may lead to a rapid decrease in oxygen flux, causing possible delays in root growth (GORNAT et al., 1971; SILBERBUSH et al., 1979), while at much lower irrigation intensity, e.g. $3 \mathrm{~mm} \cdot \mathrm{h}^{-1}$, the change in oxygen flux might be less noteworthy (GORNAT et al., 1971).

Investigating water and solute movement through the subsurface can be vital to mitigating any negative effects in agricultural applications, such as fertilizer addition. Too much fertilizer can result in nitrogen leaching, ultimately degrading the quality of nearby waters and having impact on soil biology (MORTAZAVI et al., 2013).

Correspondence to: LUBOMIR LICHNER, Institute of Hydrology, Slovak Academy of Sciences, Račianska 75, 83102 Bratislava, Slovakia.E-mail: lichner@uh.savba.sk 
Nutrient leaching can be a cause of surface and/or groundwater contamination, which could result in non-potable water (SMITH et al., 1999), eutrophication, or algal blooms (FARKAS et al., 2013; Lichner et al., 2013; ONDERKA \& PEKÁROVÁ, 2008; RABALAIS et al., 2009). Therefore, enhanced knowledge about the soil matrices of cultivated lands can be a very important element of decision-making in agricultural management.

Most soil matrices are representing non-homogeneous soil structures having pores and macropores, such as roots, voids, tunnels made by small animals, resulting in non-equilibrium water flow through the subsurface (BEVEN \& GERMANN, 2013; JARVIS, 2007). In terms of preferential flow, it cannot be limited by macropores as irregular wetting patterns within the soil matrices can also affect water flow (DEKKER \& RiTSEMA, 1996). Water and solute transport in heterogeneous and variably saturated soil matrices have been studied in the past several decades by numerous researchers (BALASHOV et al., 2014; HARDELAUF et al., 2007; HARTER \& ZHANG, 1999; Horel et al., 2015; TwARAKAVI et al., 2010). Preferential flow can greatly influence both water and solute movement through the soil, as it was found by several studies (e.g. DOHNAL et al., 2009; KODESOVA et al., 2009; VOGEL et al., 2007, 2010). Vertical soil water movement also can significantly differ under different vegetation or crop lands and cultivation methods (GOVAERTS et al., 2007).

The aim of this study was to analyze solute transport using radioactive iodide through clay loam soil under either maize or grasslands during four adjacent irrigation experiments. The objective of the study was to obtain a better understanding of how water movement might affect nutrients and minerals leaching to and below the root zones. The present study was a part of a series of experiments with different agricultural crops of interest (ALAOUI et al., 1997; DUŠEK et al., 2013; LICHNER et al., 2013).

The results could help to understand the leaching of water, solutes or pollutants such as nutrient or pesticides to the root growth zone and below the root zone under different agricultural land uses. These findings could promote decision-making aimed at mitigating any negative effects associated with the water/solute transportation process.

\section{Material and methods}

\section{Field experiment and soil characteristics}

The present study embraces the second of four experiments performed in the Experimental Station of the Research Institute of Irrigation Bratislava in 19931996. The study area is located in Most pri Bratislave village $\left(48^{\circ} 08^{\prime} 27^{\prime \prime} \mathrm{N}\right.$, $17^{\circ} 14^{\prime} 41^{\prime \prime} \mathrm{E}$ ), and it is about $133 \mathrm{~m}$ above sea level. The study site has an average annual air temperature of $9.7^{\circ} \mathrm{C}$ and the average annual precipitation amount of 554 $\mathrm{mm}$. The soil is classified as a Chernozem (WRB 2006) and has a clay loam texture (SOIL SURVEY DIVISION STAFF, 1993). 
The soil profile consists of three relatively homogeneous horizons. The physical and chemical properties of the surface horizon were as follows: clay, loam and sand contents were 53, 46 and $1 \% ; \mathrm{CaCO}_{3}$ content $11.2 \%$; $\mathrm{C}_{\text {org }}$ content $1.9 \% ; \mathrm{pH}\left(\mathrm{H}_{2} \mathrm{O}\right)$ 8.2 and $\mathrm{pH}(\mathrm{KCl}) 7.8$.

Particle size distribution, bulk density and saturated hydraulic conductivity in lower depths were presented for $0.1 \mathrm{~m}$ depth increments in ALAOUI et al., (1997).

The experiment was performed at four $3 \mathrm{~m} \times 3 \mathrm{~m}$ plots. Two of them (Plots 1 and 2) were cultivated and covered by maize (Zea mays L.) in an early phase of ontogenesis, while the other two plots (Plots 3 and 4) were uncultivated and covered by grass. The experimental conditions were similar to those described by DUŠEK et al. (2013). Briefly, a radioactive tracer technique developed by LICHNER (1992) was used to measure the tracer distribution in the soil profile.

The measuring probe, used to determine tracer concentrations, consisted of a duralumin access tube (inner diameter $8 \mathrm{~mm}$, outer diameter $12 \mathrm{~mm}$ ), in which the Geiger-Müller detector (length $21 \mathrm{~mm}$, diameter $6.3 \mathrm{~mm}$ ) and the analog interface unit are connected to a nuclear analyzer with a coaxial cable. The counting rate recorded by the detector is directly proportional to the activity of the radioactive tracer (IAEA, 1975), in the present case to the mass of radioactive iodine occurring in a cylindrical volume with the radius of a few centimeters (the half-thickness of the contributing volume for the clay loam soil and ${ }^{131} \mathrm{I}^{-}$is about $1 \mathrm{~cm}$ ). It was assumed that the change in ${ }^{131} \mathrm{I}^{-}$activity is proportional to the change in soil water content.

The schematic arrangement of the probes in each plot can be seen on Fig. 1.

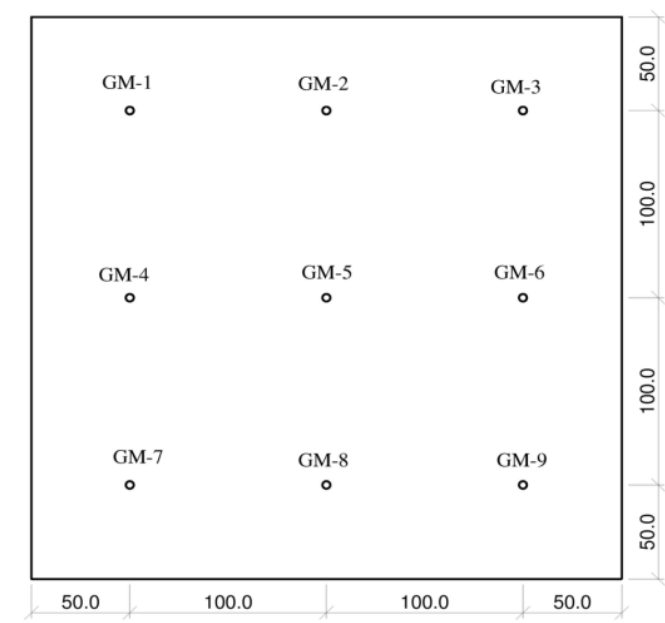

Fig. 1

The schematic arrangement of the Geiger-Müller detector probes in each plot (GM-1, 2, .. 9- probes with G-M tubes. Dimensions are in $\mathrm{cm}$.) 
Thirty six probes, nine per plot, were placed uniformly at $2 \mathrm{~m} \times 2 \mathrm{~m}$ squares at a distance of $1 \mathrm{~m}$ and inserted into the soil to a depth of $1.5 \mathrm{~m}$.

Around each probe, the narrow pulse of $\mathrm{Na}^{131} \mathrm{I}$ solution with the activity of about $10 \mathrm{MBq}(0.27 \mathrm{mCi})$ was trickled by syringe into the annulus with a diameter of about $10 \mathrm{~cm}$. Then the plots 1 and 3 were irrigated with water at a rate of 2 $\mathrm{mm} \cdot \mathrm{hr}^{-1}$ for 50 hours, and the plots 2 and 4 at a rate of $4 \mathrm{~mm} \cdot \mathrm{hr}^{-1}$ for 25 hours, to get a cumulative infiltration of $100 \mathrm{~mm}$ in all the plots (Fig. 2).

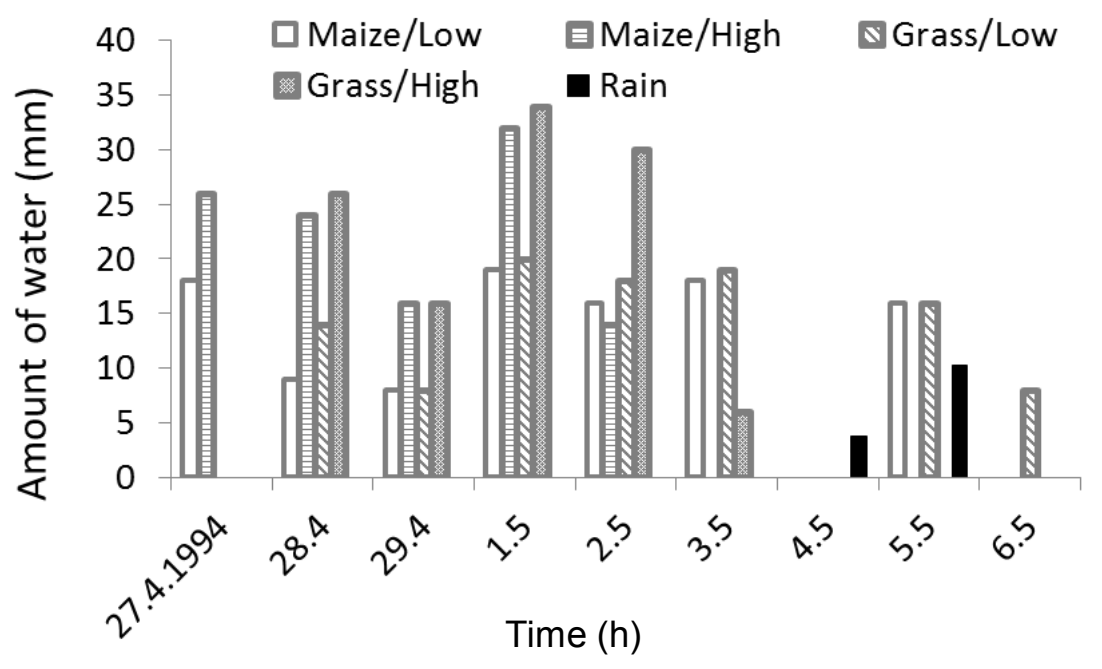

Fig. 2

Irrigation amounts, time of application and rain events during the course of the study. "Low" and "High" represents low $\left(2 \mathrm{~mm} \cdot \mathrm{h}^{-1}\right)$ and high $\left(4 \mathrm{~mm} \cdot \mathrm{h}^{-1}\right)$ irrigation intensities

The counting rates $n_{m}$ were then measured as a function of depth $z$ (with $N$ increments of $10 \mathrm{~cm}$ ) in all the probes for a cumulative water input of $100 \mathrm{~mm}$. The depth of infiltration front $z_{m}$ was also measured in all the probes for the abovementioned cumulative water inputs. Finally, true counting rates $\left(n_{t i}\right)$ and relative counting rates $\left(n_{r i}\right)$ in the probe $i$ were calculated as:

$$
\begin{gathered}
n_{t i}=\left(n_{m i}-n_{b}\right) \exp (-0.693 t / T) \\
n_{r i}=n_{t i} / \sum_{Z_{1}}^{Z n} n_{t i}
\end{gathered}
$$

where: $n_{b}$ is the counting rate of the background, $t$ is the time elapsed after the start of tracer application, and $T$ is the tracer half-time. 


\section{Statistical analysis}

Differences between site parameters were evaluated using paired, two-tailed ttest. Differences between solute transports in the study plots over time and solute amount versus depth in plots were evaluated using two-way ANOVA. Five time periods were investigated, when the total irrigation amounts reached 2, 4, 6, 8, and $10 \mathrm{~mm}$. The statistical significance in the analysis was defined at $p<0.05$.

\section{Results and Discussion}

\section{Effects of land use on water and solute movement through the subsurface}

${ }^{131} I^{-}$activity and water movement through soil profile - In all four plots most of the solute moved through the soil profile, reaching a depth of $120 \mathrm{~cm}$ during the time period investigated (Fig. 3 and 4 ). The most concentrated average ${ }^{131} \mathrm{I}^{-}$activity was observed in the top $30-40 \mathrm{~cm}$ of the soil profile, with the most pronounced activity seen at $10 \mathrm{~cm}$ below ground. These findings were relatively similar in all the plots, regardless of the type of vegetation or irrigation intensity.

Statistical analysis showed that the main effects of both depth and plots were significant $(p>0.05$; two-way ANOVA with replication, $\mathrm{n}=9)$; however the interaction between them was not $(p=0.173$; two-way ANOVA with replication, $\mathrm{n}=9)$.
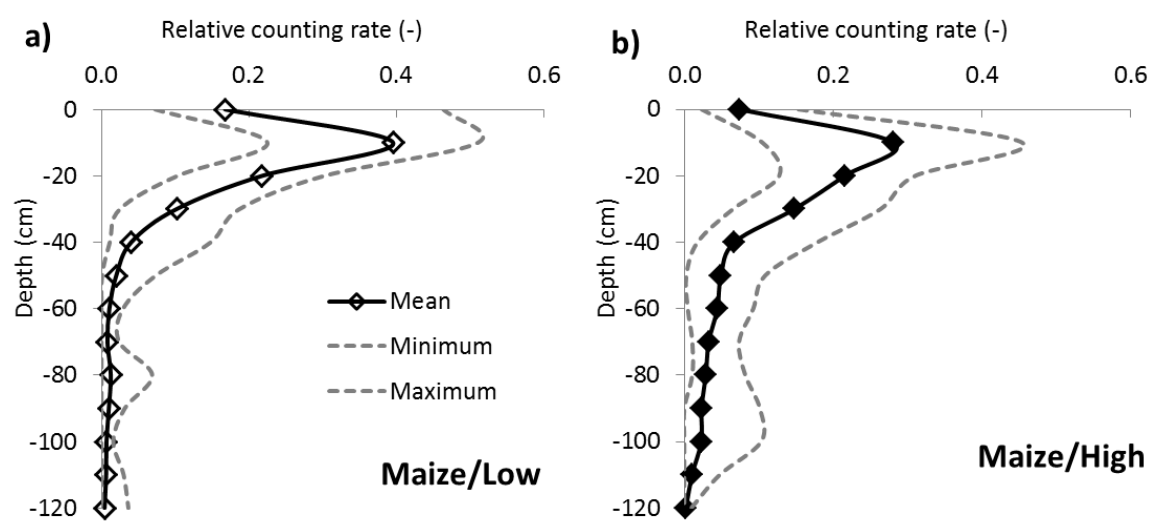

Fig. 3

Vertical iodide distributions in the soil profiles of Plot 1 (a), Plot 2 (b) with mean measured distribution (continuous line) and minimum and maximum values (dashed lines) representing measurement variability among the nine probes. The measured iodide profiles along the individual probes were determined after infiltration of $100 \mathrm{~mm}$ of water at $t=216,125.5$,

198, and $123 \mathrm{~h}$ for Plot 1, 2, 3, and 4, respectively. "Low" and "High" represents low $\left(2 \mathrm{~mm} \cdot \mathrm{h}^{-1}\right)$ and high $\left(4 \mathrm{~mm} \cdot \mathrm{h}^{-1}\right)$ irrigation intensities. 

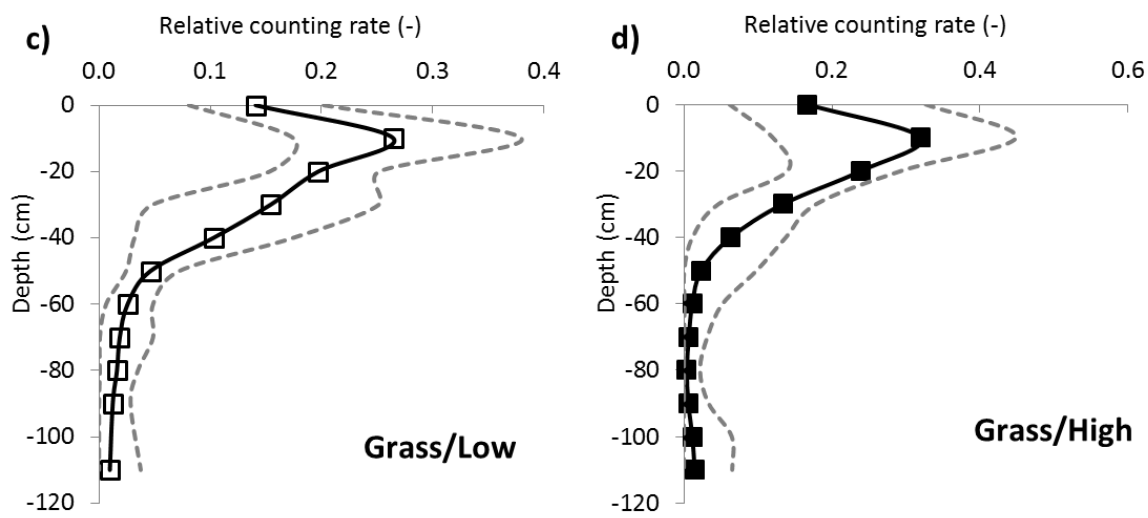

Fig. 4

Vertical iodide distributions in the soil profiles of Plot 3 (c), and Plot 4 (d) with mean measured distribution (continuous line) and minimum and maximum values (dashed lines) representing measurement variability between the nine probes. The iodide profiles measured along the individual probes were determined after the infiltration of $100 \mathrm{~mm}$ of water at $t=216,125.5,198$, and $123 \mathrm{~h}$ for Plot 1, 2, 3, and 4, respectively. "Low" and "High" represents low $\left(2 \mathrm{~mm} \cdot \mathrm{h}^{-1}\right)$ and high $\left(4 \mathrm{~mm} \cdot \mathrm{h}^{-1}\right)$ irrigation intensities.

Maize with high irrigation intensity (plot 2) and grass with low irrigation intensity (plot 3 ) had the most distinguishable maximum values compared to each other ( $p=0.007$; t-test). When the minimum values were compared, only the different irrigation intensities on grassland (plots 3 and 4) showed significant changes ( $p=$ 0.031 ; t-test).

The ${ }^{131} \mathrm{I}^{-}$activity decreased continuously with depth below the first $10 \mathrm{~cm}$ of the soil profile until reaching at approximately $80 \mathrm{~cm}$, after which, however, the ${ }^{131} \mathrm{I}^{-}$ activity started to increase, and at most study sites the counting rates $\left(n_{m}\right)$ changed most noticeably in their maximum values, as shown on Fig. 3 and 4. On grassland with high irrigation intensities, the average and maximum values of ${ }^{131} \mathrm{I}^{-}$activity increased considerably compared to data attained at a depth of $80 \mathrm{~cm}$ (with increases of $92 \%$ and an additional $27 \%$, respectively; Fig. 4 d). These changes in $n_{m}$ values distinguished the plot four soil matrices from those of the other three plots. These differences in ${ }^{131} \mathrm{I}^{-}$activity with depth and the large differences in minimum and maximum values over the course of the study indicate the preferential flow of ${ }^{131} \mathrm{I}^{-}$ through the subsurface.

\section{Effects of infiltration rates on solute concentration changes}

At the end of the experiment the largest ${ }^{131} \mathrm{I}^{-}$activity was observed for maize with an irrigation rate of $i=2 \mathrm{~mm} \cdot \mathrm{h}^{-1}$. Especially high iodide activity was measured in the root zone, which is important for crop growth, highlights the benefit of the slower rate irrigation versus the higher one in the present study. For example, the 
activity $10 \mathrm{~cm}$ below the ground was almost $41 \%$ higher in plot 1 than in plot 2 (maize with $4 \mathrm{~mm} \cdot \mathrm{h}^{-1}$ irrigation rate).

Grassland with lower irrigation intensity had relatively high ${ }^{131} \mathrm{I}^{-}$activity between $20 \mathrm{~cm}$ and $50 \mathrm{~cm}$ below the soil surface, which was the largest among all study sites. Nevertheless, the lowest average values were measured for plot 3 at depths of $10 \mathrm{~cm}$ and $20 \mathrm{~cm}$. These results suggested faster solute movement deeper into the soil profile on grassland at lower irrigation intensity compared to faster one (Fig. 4c and 4d). The opposite was for maize, where higher irrigation rates resulted in faster vertical movement through the soil matrix (Fig. 3a and 3b).

Maize land with slower irrigation rates $\left(i=2 \mathrm{~mm} \cdot \mathrm{h}^{-1}\right)$ compared with the higher $\left(i=4 \mathrm{~mm} \cdot \mathrm{h}^{-1}\right)$ showed that the slower irrigation rates saturated more the upper $20 \mathrm{~cm}$, especially at 0 and $10 \mathrm{~cm}$ below surface with 2.25 and 1.40 times higher ${ }^{131} \mathrm{I}^{-}$activity measured, respectively. The faster irrigation rate, however, had over four times higher ${ }^{131} \mathrm{I}^{-}$activity at 60 and $70 \mathrm{~cm}$ below the surface, demonstrating faster water movement through the soil matrix.

Compared with maize, the trend of water movement through the subsurface in grassland showed a reverse response to irrigation rates. The slower irrigation intensity led to much lower ${ }^{131} \mathrm{I}^{-}$activity closer to the soil surface, up to a depth of 30 $\mathrm{cm}$, after which the measurements started to increase compared to plot 4 , which had higher irrigation intensity, and remained relatively high (up to 4.1 times higher) up to a depth of $90 \mathrm{~cm}$.

Fig. 5 shows changes in soil moisture content over time for the four study sites. It is clear that the most varied responses to the different irrigation rates and plant types were recorded during the first few days of the experiment.

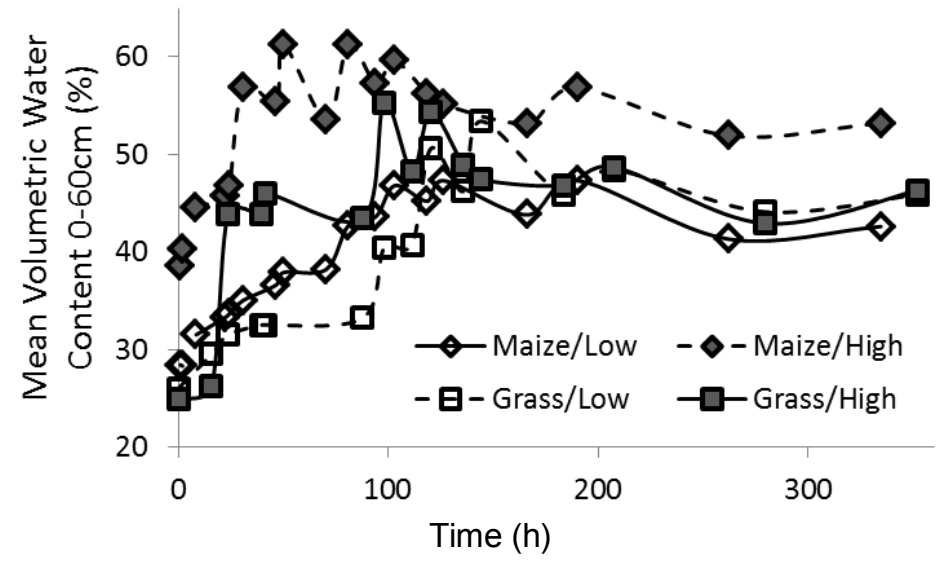

Fig. 5

Measured mean volumetric water content (\%) for the four study sites over time at a depth of 0-60 cm. "Low" and "High" represents low $\left(2 \mathrm{~mm} \cdot \mathrm{h}^{-1}\right)$ and high $\left(4 \mathrm{~mm} \cdot \mathrm{h}^{-1}\right)$ irrigation intensities. 
Overall, there was a significant difference in the ${ }^{131} \mathrm{I}^{-}$activity with depth on the two maize plots ( $p=0.038$; t-test), while no significant difference $(p=0.053$; t-test $)$ was found for the grass plots.

${ }^{131} I^{-}$counting rates over time among study sites - As the amount of water flowing through the subsurface increased, the changes in soil matrix parameters are more pronounced. As shown on Fig. 5, the most noticeable difference between the study sites at $30 \mathrm{~cm}$ below the soil surface could be observed for grassland given low intensity irrigation. The average ${ }^{131} \mathrm{I}^{-}$activity at $I=4 \mathrm{~cm}$ was $1.74-2.01$ times higher than for the other sites. This trend continued throughout the entire experiment as the total amount of $I$ reached at $10 \mathrm{~cm}$ (Fig. 6).

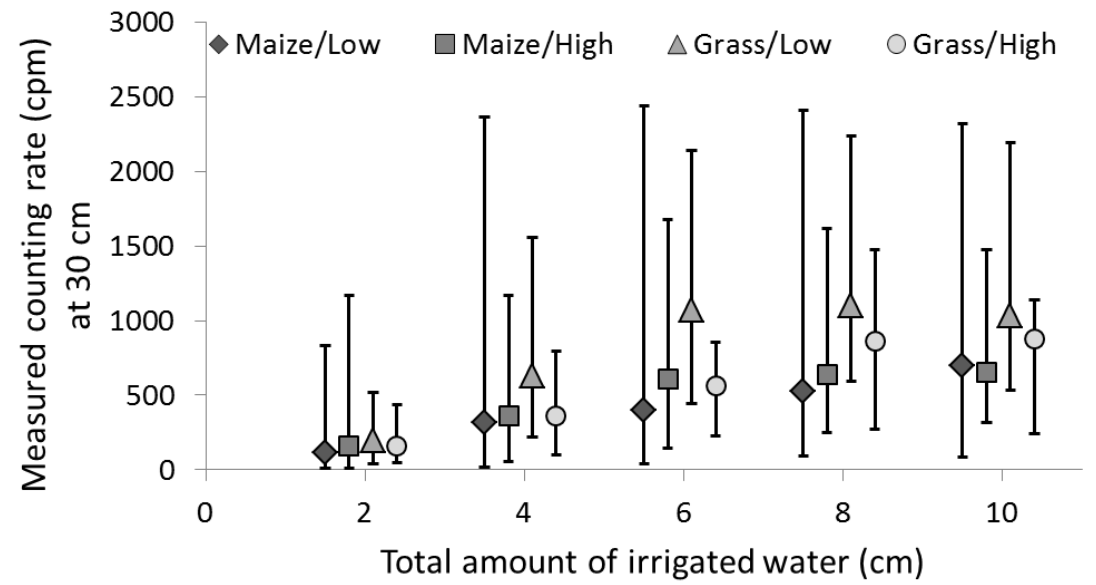

Fig. 6

Measured counting rate $(\mathrm{cpm})$ for the four study sites at different cumulative amounts of irrigation water $(I=2 \mathrm{~cm}, 4 \mathrm{~cm}, 6 \mathrm{~cm}, 8 \mathrm{~cm}$, and $10 \mathrm{~cm})$ at a depth of $30 \mathrm{~cm}$. Symbols represent mean values $(n=9)$ and error bars represent the minimum and maximum values measured among the nine probes. "Low" and "High" represents low $\left(2 \mathrm{~mm} \cdot \mathrm{h}^{-1}\right)$ and high $\left(4 \mathrm{~mm} \cdot \mathrm{h}^{-1}\right)$ irrigation intensities.

Statistical analysis revealed significant difference ( $p<0.001$; two-way ANOVA) both between plots and between the data recorded for different irrigation amounts. A previous study at a nearby location showed that the top $30 \mathrm{~cm}$ of the soil column is the most important layer for maize, as its root density and most root lengths can be found in this interval (HoREL et al., 2014).

Grasses with high root density can improve infiltration by enhancing soil porosity (PRIHAR et al., 2000); consequently grasslands can be expected to have higher infiltration rates compared to maize. However it has also been found that actively growing roots can reduce infiltration (ANGERS \& CARON, 1998).

In the present study the cumulative irrigation water $(I=10 \mathrm{~cm})$ was $1.18,1.49$ and 1.58 times higher on average for grass with low irrigation intensity than for 
grass with high irrigation intensity, and for maize with low and high irrigation intensities, respectively (Fig. 6), indicating that the grassland already had a developed root structure.

\section{Conclusions}

It was observed in the present experiment that the top $30 \mathrm{~cm}$ of the soil profile had the highest ${ }^{131} \Gamma$ activity, regardless of the type of vegetation or the irrigation intensity. In general, In general, the soil $10 \mathrm{~cm}$ below the surface had the highest ${ }^{131} \Gamma$ activity, making up between 27 and $40 \%$ of total ${ }^{131} \Gamma$ measurements (on plot 3 and 1, respectively) at the end of the investigated period. This $10 \mathrm{~cm}$ depth is crucial for good vegetation growth and crop yield, as the highest root density can be found here. It was concluded that the $2 \mathrm{~mm} \cdot \mathrm{h}^{-1}$ and $4 \mathrm{~mm} \cdot \mathrm{h}^{-1}$ irrigation intensities applied in the present study led to relatively small differences in soil water movements between maize and grassland, with somewhat more beneficial results observed when lower irrigation rate was applied in the case of maize.

\section{Summary}

The present study investigated changes in soil moisture content in fields of maize and grassland using infiltration experiments. The study explored the effects of different infiltration rates $\left(i=2 \mathrm{~mm} \cdot \mathrm{h}^{-1}\right.$ or $\left.i=4 \mathrm{~mm} \cdot \mathrm{h}^{-1}\right)$ on soil moisture and solute $\left({ }^{131} \mathrm{I}^{-}\right)$movement at different depths. The transport of radioactive iodide ${ }^{131} \Gamma$ in the structured clay loam soil was monitored during four irrigation experiments in adjacent plots. Cumulatively, $100 \mathrm{~mm}$ of water was applied. The activity of the ${ }^{131} \Gamma^{-}$ tracer was monitored as function of depth and time by Geiger-Müller $(\mathrm{G}-\mathrm{M})$ detectors in nine vertically installed access tubes per plot.

Keywords: infiltration, irrigation, structured clay loam soil, field tracer experiment, land use

The research has been supported by the Scientific Grant Agency project No. VEGA 2/0054/14 and Hungarian-Slovak Project No. MAD SNK 5/2013 - NKM 5/2014. This publication is the result of the project implementation ITMS 26240120004 Centre of excellence for integrated flood protection of land supported by the Research \& Development Operational Programme funded by the ERDF. The authors would like to thank Nandor Fodor for his help during data analyses. 


\section{References}

Alaoui, A. M., Germann, P., Lichner, L. \& NovaK, V., 1997. Preferential transport of water and ${ }^{131}$ iodide in a clay loam assessed with TDR-technique and boundary layer flow theory. Hydrol. Earth Syst. Sci. 1. 813-822.

Angers, D. A. \& CARON, J., 1998. Plant-induced changes in soil structure: Processes and feedbacks. Biogeochemistry. 42. 55-72.

Balashov, E., Buchinana, N., RizhiYa, E. \& FARKAS, Cs., 2014. Field validation of DNDC and SWAP models for temperature and water content of loamy and sandy loam Spodosols. International Agrophysics. 28. 133-142.

BeVEn, K. \& GermanN, P., 2013. Macropores and water flow in soils revisited. Water Resour. Res. 49. 3071-3092.

DeKKER, L. W. \& Ritsema, C. J., 1996. Preferential flow paths in a water repellent clay soil with grass cover. Water Resour. Res. 32. 1239-1249.

Dohnal, M., Dušek, J., Vogel, T., Císlerová, M., LiChner, L. \& ŠTeKauerová,V., 2009. Ponded infiltration into soil with biopores - field experiment and modeling. Biologia. 64. 580-584.

DuŠEK, J., Lichner, L', Vogel, T. \& ŠTeKauerovÁ, V., 2013. Transport of iodide in structured soil under spring barley during irrigation experiment analyzed using dual-continuum model. Biologia. 68. 1094-1098.

Farkas, Cs., Beldring, S., Bechmann, M. \& Deelstra, J., 2013. Soil erosion and phosphorus losses under variable land use as simulated by the INCA-P model. Soil Use and Management. 29. (s1) 124-137.

Farkas, Cs., Gelybó, G., BaKacsi, Zs., Horel, Á., Hagyó, A., Dobor, L., Kasa, I. \& TOTH, E., 2014. Impact of expected climate change on soil water regime under different vegetation conditions. Biologia. 69. 1510-1519.

FAŠKO, P., LAPIN, M. \& PECHO, J., 2008. 20-year extraordinary climatic period in Slovakia. Meteorol. Casopis. 11. 99-105.

Gornat, B., EnOCH, H. \& GoldBerG, D., 1971. The effect of sprinkling intensity and soil type on oxygen flux during irrigation and drainage. Soil Science Society of America Journal. 35. 668-670.

Govaerts, B., Fuentes, M., Mezzalama, M., Nicol, J. M., Deckers, J., Etchevers, J. D., Figuerosa-Sandoval, B. \& Sayre, K. D., 2007. Infiltration, soil moisture, root rot and nematode populations after 12 years of different tillage, residue and crop rotation managements. Soil \& Tillage Research. 94. 209-219.

Haerter, J. O., Berg, P. \& Hagemann, S., 2010. Heavy rain intensity distributions on varying time scales and at different temperatures. Journal of Geophysical Research: Atmospheres. 113. D17102, Doi:10.1029/2009JD013384.

Hardelauf, H., Javaux, M., Herbst, M., Gottshalk, S., Kasteel, R., VANDERBORGHT, J. \& VEREECKEN, H., 2007. PARSWMS: A parallelized model for simulating three-dimensional water flow and solute transport in variably saturated soils. Vadoze Zone J. 6. 255-259.

HARDY, J. T., 2003. Climate Change. Causes, Effects, and Solutions. Wiley. Chichester.

HARTER, T. \& ZHANG, D., 1999. Water flow and solute spreading in heterogeneous soils with spatially variable water content. Water Resour. Res. 35. 415-426. 
Horel, Á., Lichner, L', Alaoui, A., Czachor, H., Nagy, V. \& Tóth, E., 2014. Transport of iodide in structured clay-loam soil under maize during irrigation experiments analyzed using HYDRUS model. Biologia. 69. 1531-1538.

Horel, Á., SchiEWER, S. \& MiSRA, D., 2015. Effect of concentration gradients on biodegradation in bench scale sand columns with HYDRUS modeling of hydrocarbon transport and degradation. Environmental Science and Pollution Research. DOI: 10.1007/s11356-015-4576-6.

IAEA, 1975. Laboratory Manual on the Use of Radiotracer Techniques in Industry and Environmental Pollution. Technical Reports Series no. 161. International Atomic Energy Agency. Vienna.

JARVIS, N. J., 2007. A review of non-equilibrium water flow and solute transport in soil macropores: principles, controlling factors and consequences for water quality. European Journal of Soil Science. 58. 523-546.

Kodesova, R., Vignozzi, N., Rohoskova, M., Hajkova, T., KocareK, M., Pagliai, M., KOZAK, J. \& ŠIMŮNEK, J., 2009. Impact of varying soil structure on transport processes in different diagnostic horizons of three soil types. J. Contam. Hydrol. 104. $107-125$.

LICHNER L.,1992. Laboratory and field measurements of solute transport in soils by means of nuclear tracer technique. Vodohosp. Čas. 40. 548-561.

Lichner, L'., DuŠEK, J., DekKer, L. W., Zhukova, N., FAŠKo, P., Holko, L. \& Šír, M., 2013. Comparison of two methods to assess heterogeneity of water flow in soils. J. Hydrol. Hydromech. 61. 299-304.

Mortazavi, B., Horel, A., Anders, J. S., Mirjafari, A., Beazley, M. J. \& Sobecky, P. A., 2013. Enhancing the biodegradation of crude oil in sandy sediments with choline: a naturally methylated nitrogen compound. Env. Poll. 182. 53-62.

ONDERKA, M. \& PEKÁROVÁ, P., 2008. Retrieval of suspended particulate matter concentrations in the Danube River from Landsat ETM data. Science of the Total Environment. 397. 238-243.

Prihar, S., GAJRI, P., BenBi, R. D. K. \& Arora, V. K., 2000. Intensive Cropping: Efficient use of Water, Nutrients and Tillage. Food Products Press Inc. New YorkLondon-Oxford.

Rabalais, N. N., Turner, R. E., Diaz, R. J. \& Justic, D., 2009. Global change and eutrophication of coastal waters. Ices Journal of Marine Science. 66. 1528-1537.

Silberbush, M., Gornat, B. \& GoldBerG, D., 1979. Effect of irrigation from point source (trickling) on oxygen flux and on root extension in the soil. Plant and Soil. 52. 507-5014.

Smith, V. H., Tilman, G. D. \& NeKola, J. C., 1999. Eutrophication: impacts of excess nutrient inputs on freshwater, marine, and terrestrial ecosystems. Environmental Pollution. 100. 179-196.

SOIL SURVEY DIVISION STAFF, 1993. Soil survey manual. Soil Conservation Service. U.S. Department of Agriculture Handbook 18.

Twarakavi, N. K. C., Saito, H., Šimưnek, J. \& Van Genuchten, M. Th., 2010. Inverse modeling of vadose zone flow processes using squared $\varepsilon$-insensitivity loss function. J. Hydrol. Hydromech. 58. 188-200.

Vogel, T., Lichner, L', DuseK, J. \& CipAKovA, A., 2007. Dual-contimuum analysis of a cadmium tracer field experiment. J. Contam. Hydrol. 92. 50-65. 
Vogel, T., Brezina, J., Dohnal, M. \& Dusek, J., 2010. Physical and numerical coupling in dual-continuum modeling of preferential flow. Vadose Zone J. 9. 260267.

WRB, 2006. World reference base for soil resources 2006. $2^{\text {nd }}$ edition. World Soil Resources Reports No. 103. FAO. Rome.

ZiADAT, F. M. \& TAIMEH, A. Y., 2013. Effect of rainfall intensity, slope, land use and antecedent soil moisture on soil erosion in an arid environment. Land Degradation \& Development. 24. 582-590. 